\title{
Biliary Tract Cancer: Current Medical Treatment Strategies
}

\author{
Ester Oneda ${ }^{1, *}$, Mohammed Abu Hilal ${ }^{2}$ and Alberto Zaniboni ${ }^{1}$ \\ 1 Department of Clinical Oncology, Fondazione Poliambulanza, 25124 Brescia, Italy; \\ alberto.zaniboni@poliambulanza.it \\ 2 Department of Surgery, Fondazione Poliambulanza, 25124 Brescia, Italy; mohd.abuhilal@poliambulanza.it \\ * Correspondence: dott.ester.oneda@gmail.com
}

Received: 1 April 2020; Accepted: 12 May 2020; Published: 14 May 2020

check for updates

\begin{abstract}
Background: Biliary tract cancers (BTCs) include cholangiocarcinomas and gallbladder cancers usually present at an advanced stage, which are considered resectable in less than $20 \%$ of cases and characterised by poor prognosis. Methods: In this review, we discussed the most recent therapeutic options on the basis of the most updated and complete reviews and recent prospective studies in selected BTC patients. Results: Due to the high recurrence rate of BTCs, we suggest the new recommendations that have been made on adjuvant chemotherapy and radiotherapy treatment after surgery. New chemotherapy combinations in advanced-stage patients allow a better survival benefit than the standard treatment. Furthermore, the revelation of complex molecular events and their interactions and relationships with some risk factors allowed the development of targeted/toxic agents alone or combination with chemotherapy that is really promising. In unresectable patients, hepatic arterial infusion of high-dose chemotherapy or selective internal radiotherapy could offer a primary mass volume reduction or its resection with the maintenance of liver function. Conclusions: The therapeutic landscape for BTCs is blooming again, the knowledge of their biology is still growing, but the available data on chemotherapy, radiotherapy, locoregional treatments, and target therapies have added hopes to improve patient survival.
\end{abstract}

Keywords: cholangiocarcinoma; gallbladder cancer; chemotherapy; targeted therapy

\section{Introduction}

Tumours arising from the epithelium along the biliary tree are referred to as biliary tract cancers (BTCs), which include cholangiocarcinoma (CCA) and gallbladder cancer. Cholangiocarcinomas (CCAs) can then be differentiated by their anatomical origin into intrahepatic CCA (iCCA) and extrahepatic CCA (eCCA). Lesions involving the second-order bile ducts are defined as iCCA and accounts for 5-10\% of all CCAs. In the other hand, eCCAs are divided into perihilar CCAs (pCCAs), when they lie above the cystic duct (CD), accounting for 60-70\% of eCCAs, and distal CCAs (dCCAs), when they lie below the $\mathrm{CD}$, accounting for the remaining part [1].

Gallbladder cancer is the most frequent biliary tract cancer, comprising $80-90 \%$ according to autopsy studies [2,3], followed by CCAs, which also represents the second most common primary liver cancer accounting for nearly $15 \%$ of all liver malignancies [4] and for approximately 3\% of all gastrointestinal tumours [5]. The American Cancer Society's estimates a total of 11,980 newly diagnosed cases for approximately 4090 deaths from gallbladder and bile duct cancers in the United States for 2020 [6].

BTCs are characterized by poor prognosis, with 5-year relative survival rates ranging from $2 \%$ to $15 \%$ for iCCAs, $2 \%$ to $30 \%$ for eCCAs, and $2 \%$ to $70 \%$ for gallbladder cancer, depending on 
stage [7]. Similarly, poor mean overall survival (OS) rate for patients with CCAs (less than 24 months) and gallbladder cancer ( 6 months) has been reported [8].

Cholangiocarcinoma and gallbladder cancers occur largely after the fourth and sixth decade of life, respectively, and are more frequent in men than in women [9]. They are relatively rare in the Western world; however, higher incidence clusters have been found in some areas of Asia and the Andes [7], with the highest incidence rates of iCCAs reported in northern Thailand (113 per 100,000 person-years among men and 50 per 100,000 person-years among women), possibly due to genetic and environmental differences [9]. In fact, endemic fluke Opisthorchis viverrini (a flatworm that infects humans via ingestion of raw or pickled fish) infection in this area has been reported, and CCA makes up $89 \%$ of primary liver cancers [9].

Other risk factors for CCA are parasitic infections; bile duct disorders, such as primary sclerosing cholangitis (PSC), biliary cysts, or ductal stone disease; toxins; viral hepatitis, such as hepatitis C and B. These risk factors are associated with chronic inflammation of the biliary tree and liver injury that predispose the affected individuals to carcinogenesis [5].

Gallbladder cancer, instead, has a particularly high incidence in Chile, Japan, and northern India [2] and is commonly associated with chronic inflammation, with metaplasia progressing to dysplasia, carcinoma in situ, and then, invasive cancer. Gallstone disease, gallbladder polyps, chronic Salmonella infection, congenital biliary cysts, and abnormal pancreaticobiliary duct junction have been reported as important precursors [2].

Biliary tract cancers usually present at an advanced stage, with less than $20 \%$ of patients considered resectable at presentation [7]. In addition, when possible, adjuvant therapy is usually indicated to improve rates of relapse-free survival (RFS) and overall survival (OS) [7]. In non-operable patients, stent placement can be offered to treat obstructive jaundice, control symptoms such as pruritus, biliary cirrhosis, and cholangitis and decrease related secondary morbidity [10]. Endobiliary techniques have made notable progress, improving stent median patency with self-expanding bare-metal stents (SEMS) [10] and offering local disease control with novel therapies, such as radiofrequency ablation (RFA), photodynamic therapy (PDT), and irreversible electroporation (IRE), thus providing a wider window for administration of cytotoxic therapy to a larger pool of patients [11].

Studies of adjuvant treatment options have historically been small, retrospective, and non-randomized and include a mixture of patients with gallbladder and other biliary tract tumours. Recently, results from prospective trials of adjuvant therapy for BTC have been published and have made a step forward in the current recommendations [7]. In the advance setting, during the past decade, the evidence base for the treatment consisted of gemcitabine-cisplatin as front line regimen [12], but the median overall survival was under 1 year. In order to improve outcomes, novel targeted/toxic agents alone or in combination with chemotherapy are under investigation.

The purpose of this review is to analyse and discuss the latest therapeutic options, including adjuvant, first- and second-line chemotherapy, targeted therapies, combination treatments, and locoregional therapies, for patients with biliary tract cancers.

In recent years, some studies have focused on BTC behaviour and their prognosis by anatomical site, their responsivity to chemotherapeutic agents and their molecular pathophysiology, finding new treatment options, and carcinogenic role of some genes, and genes affected by copy number alterations which can benefit from targeted therapy. We herein discuss these latest therapeutic strategies and their possible future applications.

\section{Results}

\subsection{Chemotherapy Treatment}

\subsubsection{Adjuvant Therapy}

Three important Phase III randomised clinical trials, comparing chemotherapy treatment to observation alone in resected BTC patients, have been published in the last 2 years [13-15]. The BCAT 
trial and the PRODIGE-12/ACCORD-18 trial have failed to show any benefit with gemcitabine (Gem) or with the combinations of gemcitabine and oxaliplatin (GemOx) chemotherapy in patients with resected BTC when compared to an observation alone arm $[13,14]$. Unlike the previous two trials, the BILCAP trial [15] have interestingly shown a significant benefit in terms of OS associated with capecitabine (Cap), administered for eight cycles, vs. observation alone (OS 51.1 months, 95\% CI 34.6-59.1 vs. 36.4 months, 95\% CI 29.7-44.5). Even though the BILCAP study did not meet its primary end-point goal (pre-planned target HR of 0.69), in the ITT population, a significant survival benefit of 53 months associated with Cap vs. 36 months associated with observation alone (HR 0.81 (95\% CI 0.63-1.04); $p$-value 0.097$)$ has been reported. In addition, a significant benefit in terms of RFS (24.4 months (95\% CI 18.6-35.9) vs. 17.5 months (95\% CI 12.0-23.8); HR 0.75 (95\% CI 0.58-0.98); $p$-value 0.033 ) has been noted. These trials were compared in different meta-analyses. and their results are summarised in Table 1.

Table 1. Summary of adjuvant treatments.

\begin{tabular}{|c|c|c|c|c|}
\hline Study & $\begin{array}{c}\text { Number and Type } \\
\text { of Patients }\end{array}$ & Study Arms & RFS & os \\
\hline $\begin{array}{l}\text { Primrose et al. [15] } \\
\text { randomised, controlled, } \\
\text { multicentre, phase III } \\
\text { BILICAP trial }\end{array}$ & $\begin{array}{c}447 \text { CCA or } \\
\text { muscle-invasive } \\
\text { gallbladder cancer }\end{array}$ & $\begin{array}{c}\text { Cap: } 1250 \mathrm{mg} / \mathrm{m}^{2} \text { twice } \\
\text { a day on days } 1 \text { to } 14 \text { of } \\
\text { a 3-week cycle for } 24 \text { weeks } \\
\text { (8cycles) } \\
\text { vs. } \\
\text { Obs }\end{array}$ & $\begin{array}{c}\text { Cap: } 24.6 \text { months }(95 \% \text { CI, } \\
18.9 \text { to } 36.7 \text { months) } \\
\text { Obs: } 17.6 \text { months }(95 \% \text { CI, } \\
12.8 \text { to } 27.6 \text { months) } \\
\text { HR } 0.76(95 \% \text { CI, } 0.58 \text { to } 0.99 \text {; } \\
\quad p=0.039)\end{array}$ & $\begin{array}{c}\text { Cap: } 51.1 \text { months ( } 95 \% \text { CI, } \\
34.6 \text { to } 59.1 \text { months) } \\
\text { Obs: } 36.4 \text { months ( } 95 \% \text { CI, } \\
29.7 \text { to } 44.5 \text { months) } \\
\text { HR: } 0.81 \text { ( } 95 \% \text { CI, } 0.63 \text { to } \\
1.04 ; p=0.097)\end{array}$ \\
\hline $\begin{array}{c}\text { Edeline et al. [14] } \\
\text { multicentre, open-label, } \\
\text { randomised phase III } \\
\text { PRODIGE 12-ACCORD } 18 \\
\text { trial }\end{array}$ & 196 resected BTC & $\begin{array}{c}\text { Gem } 1000 \mathrm{mg} / \mathrm{m}^{2} \text { on day } 1 \\
\text { and oxaliplatin } 85 \mathrm{mg} / \mathrm{m}^{2} \text { on } \\
\text { day } 2 \text { for } 12 \text { cycles } \\
\text { vs. } \\
\text { Surveillance }\end{array}$ & $\begin{array}{c}\text { GemOx: } 30.4 \text { months } \\
\text { (95\% CI, } 15.4 \text { to } 43.0 \text { months) } \\
\text { Surveillance: } 18.5 \text { months } \\
\text { (95\% CI, } 12.6 \text { to } 38.2 \text { months) } \\
\text { HR 0.71 (95\% CI, } 0.62 \text { to } 1.25 \text {; } \\
\quad p=0.48)\end{array}$ & $\begin{array}{c}\text { GemOx: } 24 \text {-months OS } 69 \% \\
48 \text {-months OS } 51 \% \\
72 \text {-months OS } 51 \% \\
\text { Surveillance: } 24 \text {-months OS } \\
76 \% \\
48 \text {-months OS } 52 \% \\
72 \text {-months OS } 48 \%\end{array}$ \\
\hline $\begin{array}{c}\text { Ebata et al. [13] } \\
\text { randomised phase III } \\
\text { BCAT trial }\end{array}$ & 225 resected BTC & $\begin{array}{c}\text { Gem } 1000 \mathrm{mg} / \mathrm{m}^{2} \text { on days } \\
1,8 \text {, and } 15 \text { every } 4 \text { weeks (6 } \\
\text { cycles) } \\
\text { vs. } \\
\text { Obs }\end{array}$ & $\begin{array}{c}\text { Gem: } 36.0 \text { months } \\
\text { Obs: } 39.9 \text { months } \\
\text { HR } 0.93 \text { (95\% CI, } 0.66 \text { to } 1.32 \text {; } \\
\quad p=0.693)\end{array}$ & $\begin{array}{c}\text { Gem: } 62.3 \text { months } \\
\text { Obs: } 63.8 \text { months } \\
\text { HR 1.01 (95\% CI, } 0.70 \text { to } 1.45 \text {; } \\
p=0.964)\end{array}$ \\
\hline $\begin{array}{l}\text { Kobayashi et al. [16] } \\
\text { multicentre, randomised } \\
\text { phase II KHBO } 1208 \text { trial }\end{array}$ & $\begin{array}{l}70 \text { BTC after major } \\
\text { hepatectomy }\end{array}$ & $\begin{array}{c}\text { Gem } 1000 \mathrm{mg} / \mathrm{m}^{2} \text { on days } 1 \\
\text { and } 8 \text { every } 2 \text { weeks } \\
\text { vs. } \\
\text { S1 } 80 \mathrm{mg} / \mathrm{m}^{2} / \text { day for } 28 \text { days } \\
\text { every } 6 \text { weeks }\end{array}$ & $\begin{array}{l}1 \text {-year } 51.4 \% \text { vs. } 62.9 \% \\
2 \text {-year } 31.4 \% \text { vs. } 51.4 \%\end{array}$ & $\begin{array}{c}\text { 1-year } 80 \% \text { vs. } 97.1 \% \text { HR } \\
0.48 \text { (CI } 90 \%, 0.24-0.93) \\
\text { 2-year } 60 \% \text { vs. } 80 \%\end{array}$ \\
\hline $\begin{array}{l}\text { Nakachi et al. [17] } \\
\text { open-label, multicentre, } \\
\text { randomised phase III } \\
\text { ASCOT trial }\end{array}$ & 350 resected BTC & $\begin{array}{c}\text { S1: } 40-60 \mathrm{mg} / \text { day related to } \\
\text { BSA (body surface area) } \\
\text { vs. Obs }\end{array}$ & n.a & 3-year OS n.a vs. $47 \%$ \\
\hline $\begin{array}{c}\text { Stein et al. [18] randomised, } \\
\text { multidisciplinary, } \\
\text { multinational phase III } \\
\text { ACTICCA-01 trial }\end{array}$ & $\begin{array}{l}\text { CCA } \\
\text { and gallbladder } \\
\text { cancer }\end{array}$ & $\begin{array}{c}\text { Cis/Gem on days } 1 \text { and } 8 \\
\text { every } 3 \text { weeks, Cisplatin } \\
\left(25 \mathrm{mg} / \mathrm{m}^{2}\right) \text { and Gemcitabine } \\
\left(1000 \mathrm{mg} / \mathrm{m}^{2}\right) \text { vs. } \\
\text { Cap from days } 1 \text { to } 14 \text { every } \\
3 \text { weeks }\left(1250 \mathrm{mg} / \mathrm{m}^{2}, \text { twice }\right. \\
\text { daily) }\end{array}$ & n.a & n.a \\
\hline
\end{tabular}

$\mathrm{CCA}=$ cholangiocarcinoma; $\mathrm{BTC}=$ biliary tract cancer; $\mathrm{Gem}=$ gemcitabine $;$ Cap = capecitabine; Obs = observation; $\mathrm{S} 1$ = tegafur/gimeracil/oteracil; Cis = cisplatin; OS = overall survival; RFS = relapse-free survival; .a = not available; $\mathrm{DFS}=$ disease free survival; $\mathrm{CI}=$ confidence interval.

A meta-analysis from Messina et al. [19] has shown that adjuvant CT provides a mild benefit in terms of RFS (HR: 0.83, 95\% CI 0.69-0.99) and effect on OS, but not in the overall population (HR: 0.91, 95\% CI 0.75-1.09) nor the node positive subgroup (HR: 0.84, 95\% CI 0.65-1.08), despite a higher risk of $\geq$ G3-G4 adverse events (AEs; RR: 3.03, 95\% CI 2.22-4.15). In contrast, Caparica et al. [20], analyzing those three clinical trials, stated that no difference in OS was observed between chemotherapy and observation, whereas a significant improvement was seen in RFS. Furthermore, a trend in benefit from adjuvant chemotherapy was observed in $\mathrm{N}+$ patients. However, the lack of individual patient data, long recruitment periods, differences in clinical trial design, heterogeneity in CT regimens and patient's characteristics, different access to chemotherapy delivered after disease recurrence, and no stratification 
of patients according to BTC subtype could have skewed the results [19]. Lamarca et al. [21] found other limitations in the design of these studies, such as follow-up time, power, and data maturity.

Based on these findings, the ASCO guidelines have [7] recommended adjuvant capecitabine for a period of six months following curative resection of BTCs (CCA and GBC). Researchers agree on the fact that 12-16 weeks of recovery time is required after surgery prior to starting adjuvant therapy, and the administration of chemotherapy during a limited period of time (rather than until disease recurrence) is accepted as standard practice in the adjuvant setting and has been shown to be safe. Finally, based on the data available, chemotherapy based on fluoropyrimidines seems to be preferable [22].

This was also confirmed by the Japanese Phase II randomized KHBO 1208 trial [16] that compared 6-months of CT with biweekly Gem to tegafur/gimeracil/oteracil (S-1) in BTC Asian patients after major hepatectomy. S-1 has shown superior outcomes $(p<0.10)$ in terms of OS and 2-year RFS. Nowadays, the Phase III Japanese ASCOT trial is testing S-1 vs. observation in patients with resected BTC [17], while the multinational ACTICCA-01 trial [18] is testing cisplatin plus gemcitabine (the CisGem regimen), which is the current standard of care in patients with advanced disease and in patients with curatively resectable disease (Table 1 shows their regimen schedules). Moreover, the trial also plans to test adjuvant radiotherapy after $\mathrm{R} 1$ resection (and no disease progression after adjuvant chemotherapy).

\subsubsection{Neoadjuvant Therapy}

Neoadjuvant therapy could allow us to treat more patients than adjuvant therapy; this suggestion is mainly based on the observation that only $55 \%$ of patients who received capecitabine in the BILCAP trial have completed the planned eight cycles of treatment. However, neoadjuvant chemotherapy administration is not always possible due to the patient symptoms such as jaundice or other morbidities that could hold back treatment administration [23]. Unfortunately, no studies have been published on this specific area.

\subsubsection{Advanced Disease: First-Line Treatment}

The milestone of first-line treatment for BTC comes from the ABC-02 study [12] that suggested the efficacy of gemcitabine-cisplatin (GemCis) chemotherapy. Although this regimen has remained the standard of care, the median overall survival is still reported at just under 1 year [24]. Shroff et al. [25] demonstrated that the addition of nab-paclitaxel to standard doublet therapy (known as the GAP regimen: gemcitabine, nab-paclitaxel, and cisplatin) has improved survival. Notably, owing to poor tolerability observed, Gem and nab-paclitaxel doses were reduced by $20 \%$ from the standard dose. Interestingly, 12 patients were converted to resectable disease and completed surgery, 2 of whom achieved a pathologically complete response (PCR). Only $16 \%$ of patients withdrew owing to adverse effects, despite the high rate $(58 \%)$ of grade 3 or higher adverse events [24,25]. The reduced-dose triplet is being evaluated against GemCis in the ongoing Phase III SWOG 1815 trial (NCT03768414).

The superiority of the combination regimen of folinic acid, fluoropyrimidine, irinotecan, and oxaliplatin (FOLFIRINOX) over Gem in pancreatic cancer patients [26] has led to the rationale for using this regimen in BTC patients. In a small retrospective series, FOLFIRINOX, as first-line treatment for BTC, has led to a disease control rate of $75 \%$ and OS of 15 months [27,28]. The ongoing Phase II/III PRODIGE38-AMEBICA trial (NCT02591030) aims to demonstrate an improvement in OS of 4 months in favour of the modified FOLFIRINOX (no 5-FU bolus on day 1) vs. GemCis [29]. The NIFE Phase II trial aims to challenge the current palliative first-line therapy for BTC by the use of nanoliposomalirinotecan/5-FU/leucovorin (nal-IRI). This trial is based on the assumption that $\geq 60 \%$ of patients will be progression-free after 4 months of nal-IRI [30]. In Table 2, first-line treatments are compared. 
Table 2. Summary of first-line treatments in advanced settings.

\begin{tabular}{|c|c|c|c|c|}
\hline & & Fist Line & & \\
\hline Study & $\begin{array}{l}\text { Number and Type } \\
\text { of Patients }\end{array}$ & Study Arms & PFS & OS \\
\hline $\begin{array}{l}\text { Valle et al. [12] Phase III } \\
\text { ABC-02 trial }\end{array}$ & $\begin{array}{l}410 \text { locally advanced or } \\
\text { metastatic CCA, gallbladder } \\
\text { cancer, or ampullary cancer }\end{array}$ & $\begin{array}{l}\text { GemCis: cisplatin } 25 \mathrm{mg} / \mathrm{m}^{2} \text { followed } \\
\text { by Gem } 1000 \mathrm{mg} / \mathrm{m}^{2} \text { (on days } 1 \text { and } 8, \\
\text { every } 3 \text { weeks for } 8 \text { cycles) vs. Gem } \\
\text { alone } 1000 \mathrm{mg} / \mathrm{m}^{2} \text { (on days } 1,8, \\
\text { and } 15 \text {, every } 4 \text { weeks for six cycles) } \\
\text { for up to } 24 \text { weeks. }\end{array}$ & 8.0 vs. 5.0 months & $\begin{array}{l}11.7 \text { vs. } 8.1 \text { months } \\
\text { HR }(0.64 ; 95 \% \\
\text { confidence interval, } \\
0.52 \text { to } 0.80 ; \\
p<0.001)\end{array}$ \\
\hline $\begin{array}{l}\text { Shroff et al. [25] open-label, } \\
\text { single-arm, Phase II trial }\end{array}$ & 60 advance BTC & $\begin{array}{l}\text { GAP: Gem } 1000 \mathrm{mg} / \mathrm{m}^{2} \text {, cisplatin, } \\
25 \mathrm{mg} / \mathrm{m}^{2}, \text { and nab-paclitaxel, } \\
125 \mathrm{mg} / \mathrm{m}^{2} \text {, on days } 1 \text { and } 8 \\
\text { of } 21 \text {-day cycles }\end{array}$ & $\begin{array}{c}11.8 \text { months } \\
\text { (95\% CI, } 6.0 \text { to } 15.6)\end{array}$ & $\begin{array}{l}19.2 \text { months } \\
(95 \% \text { CI, } 13.2 \\
\text { months to not } \\
\text { estimable) }\end{array}$ \\
\hline $\begin{array}{l}\text { Phelip et al. [29] Phase } \\
\text { II/III trial } \\
\text { PRODIGE38-AMEBICA } \\
\text { trial }\end{array}$ & $\begin{array}{l}\text { intra or extra hepatic or hilar } \\
\text { or gallbladder carcinoma }\end{array}$ & $\begin{array}{c}\text { FOLFIRINOXm Oxali } 85 \mathrm{mg} / \mathrm{m} 2, \text { IRI } \\
180 \mathrm{mg} / \mathrm{m}^{2} \text { (IV } 90 \mathrm{~min} \text { ), folinic acid } \\
400 \mathrm{mg} / \mathrm{m}^{2} \text { (IV } 2 \mathrm{~h} \text { ), } 5 \mathrm{FU} 2400 \mathrm{mg} / \mathrm{m}^{2} \\
(46 \mathrm{~h} \text { ) every } 2 \text { weeks vs. GemCIs: } \\
\text { cisplatin } 25 \mathrm{mg} / \mathrm{m}^{2} \text { followed by Gem } \\
1000 \mathrm{mg} / \mathrm{m}^{2} \text { (on days } 1 \text { and } 8 \text { ) } \\
\text { every } 3 \text { weeks }\end{array}$ & n.a & n.a \\
\hline $\begin{array}{c}\text { Berger et al. [30] Phase II } \\
\text { NIFE trial }\end{array}$ & $\begin{array}{l}\text { locally advanced, } \\
\text { non-resectable } \\
\text { or metastatic BTC }\end{array}$ & $\begin{array}{c}\text { Nal-IRI: nal-IRI mg/m } \mathrm{m}^{2} \text { (46h infusion), } \\
\text { 5-FU } 2400 \mathrm{mg} / \mathrm{m}^{2} \text { ( } 46 \mathrm{~h} \text { infusion), } \\
\text { leucovorin } 400 \mathrm{mg} / \mathrm{m}^{2} \text { (0.5 h infusion) } \\
\text { on day } 1 \text { every } 2 \text { weeks } \\
\text { Vs. GemCis: cisplatin } 25 \mathrm{mg} / \mathrm{m}^{2} \\
\text { followed by Gem } 1000 \mathrm{mg} / \mathrm{m}^{2} \text { (on } \\
\text { days } 1 \text { and } 8 \text { ) every } 3 \text { weeks }\end{array}$ & n.a & n.a \\
\hline
\end{tabular}

\subsubsection{Advanced Disease: Beyond the First Line}

After first-line therapy, $25 \%-50 \%$ of patients who progressed were still able to receive second-line chemotherapy (CT2) [31]. Discordant opinions have been suggested regarding the potential benefit of CT2 with a marginal activity (RR 7.2\%, DCR $49.5 \%$ ), and limited efficacy in unselected populations (OS 7.2 months, PFS 3.2 months). The ABC-06 Phase III trial demonstrated OS benefit with the modified combination of folinic acid, fluorouracil and oxaliplatin (mFOLFOX6) plus active symptom control (ASC) vs. the effect of ASC alone, in patients who had progressed to first-line GemCis. Notably, the effect of mFOLFOX6 was maintained regardless of previous platinum sensitivity, and $20 \%$ of patients experienced disease control of at least 9 months [21]. However, the study did not compare mFOLFOX6 regimen with a fluoropyrimidine alone arm, so it was not clear if the combination therapy was more efficient than monotherapy in this setting [32]. CT2 with the combination of mitomycin C and capecitabine vs. capecitabine alone yielded poor outcomes; oxaliplatin plus irinotecan (XELIRI) achieved PFS and OS benefit over irinotecan monotherapy [33] in a Chinese population the combination of folinic acid, fluorouracil and irinotecan (FOLFIRI) plus bevacizumab [34] and the sequence Gemox-FOLFIRI achieved 21.9 months OS in a small patient series [35]. In addition, trifluridine/tipiracil (FTD/TPI) was tested in BTC patients in II-line; as expect, no objective response (OR) was seen [36], although $60 \%$ of patients had been treated with up to three chemotherapy lines. A Phase II single-arm trial evaluating the combination of FTD/TPI and irinotecan for patients with refractory BTC is ongoing (NCT04072445), supporting the idea that this combination will likely have a higher response rate. The meta-analysis from Ying and Chen [37] has indicated that 1-year OS was 21.1\% for a single targeted agent, $29.6 \%$ for a single toxic agent (mainly fluoropyrimidine alone), $26.9 \%$ for gemcitabine-based combination therapy, and $23.3 \%$ for taxanes-based combination therapy; in fact, in all cases, it was higher than the $15 \%$ observed in fluoropyrimidine-based combination therapy. However, no head-to-head comparison data were available for combination therapy vs. monotherapy [37].

These studies (summarised in Table 3) have shown heterogeneous results which emphasises the need of an appropriate selection of patients. Many single institutional studies have tried to define some prognostic tools for selecting patients who could benefit from CT2, such as age, performance 
status, surgery for primary tumour, a good response to first-line therapy, PFS longer than 6 months, neutrophil-to-lymphocyte ratio, and carcinoembryonic antigen, CA19-9, leucocyte, cholinesterase and albumin concentrations [32]. Only one multicentre European study has developed and validated (in three countries) a prognostic model based on four independent prognostic factors: the baseline performance status, the reason of ending the first line-therapy, surgical treatment for the primary tumour, and the presence of peritoneal carcinomatosis [32].

Table 3. Summary of treatments in advanced settings.

\begin{tabular}{|c|c|c|c|c|}
\hline \multicolumn{5}{|c|}{ After First-Line } \\
\hline Study & $\begin{array}{c}\text { Number and Type of } \\
\text { Patients }\end{array}$ & Study Arms & PFS & OS \\
\hline $\begin{array}{c}\text { Lamarca et al. [21] } \\
\text { randomised phase III, } \\
\text { multi-centre, open-label } \\
\text { ABC-06 trial }\end{array}$ & $\begin{array}{l}162 \text { locally } \\
\text { advanced/metastatic BTC } \\
\text { patients previously-treated } \\
\text { with CisGem chemotherapy }\end{array}$ & $\begin{array}{c}\text { ASC }+\mathrm{mFOLFOX6:} \mathrm{Oxali} \\
85 \mathrm{mg} / \mathrm{m}^{2}, \text { folinic acid } \\
350 \mathrm{mg} / \mathrm{m}^{2}, 5-\mathrm{FU} 400 \mathrm{mg} / \mathrm{m}^{2} \\
\text { (bolus) and } 2400 \mathrm{mg} / \mathrm{m}^{2} \\
\text { (infusion) every } 2 \text { weeks for } \\
12 \text { cycles } \\
\text { vs. } \\
\text { ASC }\end{array}$ & & $\begin{array}{c}\text { mOS: } 6.2 \text { vs. } 5.3 \text { months HR: } \\
\text { 0.69 (95\% CI 0.50-0.97; } \\
p=0.031) \\
\text { 6-months OS: } 50.6 \% \\
\text { vs. } 35.5 \% \\
\text { 12-months OS: } 25.9 \% \\
\text { vs. } 11.4 \%\end{array}$ \\
\hline $\begin{array}{l}\text { Zheng et al. [33] } \\
\text { randomised, Phase II study }\end{array}$ & $\begin{array}{l}64 \text { advanced BTC patients } \\
\text { progressed after CisGem }\end{array}$ & $\begin{array}{c}\text { XELIRI: IRI } 180 \mathrm{mg} / \mathrm{m}^{2} \text { on } \\
\text { day } 1, \text { cap } 1000 \mathrm{mg} / \mathrm{m}^{2} \text { twice } \\
\text { daily on days } 1-10 \text { every } 2 \\
\text { weeks vs. } \\
\text { Irinotecan: IRI } 180 \mathrm{mg} / \mathrm{m}^{2} \\
\text { every } 2 \text { weeks }\end{array}$ & 3.7 vs. 2.4 months & $\begin{array}{c}\text { 9-month OS: } 60.9 \% \text { vs. } 32.0 \% \\
\text { mOS } 10.1 \text { vs. } 7.3 \text { months } \\
\text { DCR: } 63.3 \% \text { vs. } 50.0 \%\end{array}$ \\
\hline Guion-Dusserre et al. [34] & $\begin{array}{l}13 \text { metastatic intrahepatic } \\
\text { CCA patients who were } \\
\text { refractory to GemOx }\end{array}$ & $\begin{array}{l}\text { FOLFIRI + bevacizumab: } \\
\text { IRI } 180 \mathrm{mg} / \mathrm{m}^{2}(\mathrm{IV} 90 \mathrm{~min}) \\
\text { folinic acid } 400 \mathrm{mg} / \mathrm{m}^{2}(\mathrm{IV} \\
\text { 2h), } 5 \text {-FU } 2400 \mathrm{mg} / \mathrm{m}^{2}(46 \mathrm{~h}) \\
\text { bevacizumab }(5 \mathrm{mg} / \mathrm{kg}) \\
\text { every } 2 \text { weeks }\end{array}$ & $\begin{array}{l}8 \text { months (95\% CI: } \\
7-16 \text { months) }\end{array}$ & $\begin{array}{c}20 \text { months (95\% CI: } 8-48 \\
\text { months) } \\
\text { DCR: } 84.5 \%(95 \% \text { CI: } \\
42 \%-100 \%) \\
\text { ORR: } 38.4 \%(95 \% \text { CI: } \\
12.5 \%-89 \%)\end{array}$ \\
\hline $\begin{array}{l}\text { Sebbagh et al. [35] } \\
\text { retrospective trial }\end{array}$ & $\begin{array}{c}52 \text { recurrent/advanced BTC } \\
\text { patients after progression } \\
\text { to GemOx }\end{array}$ & $\begin{array}{l}\text { FOLFIRI (after GemOx in } \\
\text { fist line): IRI } 180 \mathrm{mg} / \mathrm{m}^{2} \text { (IV } \\
90 \mathrm{~min}), \text { folinic acid } \\
400 \mathrm{mg} / \mathrm{m}^{2}(\mathrm{IV} 2 \mathrm{~h}), 5 \text {-FU } \\
2400 \mathrm{mg} / \mathrm{m}^{2}(46 \mathrm{~h})\end{array}$ & $\begin{array}{l}\text { Fist-line GemOx: } \\
4.8 \text { months } \\
\text { Second-line } \\
\text { FOLFIRI: } \\
3.2 \text { months }\end{array}$ & 21.9 months \\
\hline $\begin{array}{l}\text { Chakrabarti et al. [36] } \\
\text { Phase II trial }\end{array}$ & $\begin{array}{l}27 \text { advanced BTC } \\
\text { previously treated }\end{array}$ & FTD/TPI 35 mg $/ \mathrm{m}^{2} /$ day & $\begin{array}{l}3.8 \text { months ( } 95 \% \mathrm{CI} \text {, } \\
2.0 \text { to } 5.8 \text { months) }\end{array}$ & $\begin{array}{l}6.1 \text { months ( } 95 \% \mathrm{CI}, 4.4 \\
\text { to } 11.4 \text { months) }\end{array}$ \\
\hline \multicolumn{5}{|c|}{$\begin{array}{l}\mathrm{CCA}=\text { cholangiocarcinoma; } \mathrm{BTC}=\text { biliary tract cancer; Gem = gemcitabine; CisGem = cisplatin, gemcitabine; } \\
\text { Cap = capecitabine; obs = observation; } \mathrm{Cis}=\text { cisplatin; Oxali = oxaliplatin; IRI = irinotecan; } 5 \text {-FU = 5-fluorouracil; } \\
\text { GemOx = gemcitabine, oxaliplatin; FTD/TPI = trifluridine/tipiracil; ASC = active symptom control; OS = overall } \\
\text { survival; TTP = time to progression; PFS = progression free survival; DCR = disease control rate; ORR = objective } \\
\text { response rate; CI = confidence interval. }\end{array}$} \\
\hline
\end{tabular}

\subsection{Radiotherapy}

As stated by European Society of Medical Oncology(ESMO) guidelines, radiotherapy may be considered for certain patients, but there is limited clinical evidence for its effectiveness; therefore they are not currently commonly used in Europe outside of clinical trials. In particular, radiotherapy can be used to relieve some symptoms of biliary tract cancer-like pain and other symptoms by shrinking tumours that block blood vessels or bile ducts, or press on nerves [38]. A retrospective analysis of inoperable iCCA patients treated with definitive radiation therapy suggested that a biologically effective dose (BED) > 80.5 Gy seems to be ablative, with long-term survival rates that compare favorably to resection [39]. The metanalysis of Ren et al. showed a 5-year OS benefit for eCCA and gallbladder cancer patients treated with adjuvant radiotherapy than without, with a major benefit in for those with lymph node-positive disease (OR $=0.15 ; 95 \%$ CI 0.07-0.35; $p<0.00001$ ) and margin-positive disease $(\mathrm{OR}=0.40 ; 95 \% \mathrm{CI} 0.19-0.85 ; p=0.02)$ [40]. Manterola et al. [41] have completed a literature review on the combination of chemo-radiotherapy (CRT) with fluoropyrimidines as a radio-sensitizer in the adjuvant setting or radiotherapy (RT) alone for resected gallbladder cancer. The effectiveness of adjuvant CRT continues to be controversial, although, in the SWOG080 trial, adjuvant CT with gemcitabine plus capecitabine (Gem-cape) followed by concomitant chemoradiation resulted in an impressive 2-year OS rate of 65\% (95\% CI, 53\%-74\%) among 79 patients with resected 
BTC, independently of the resection margin status [42]. Unfortunately, the paucity and low quality of data, including the lack of direct comparisons, did not permit a consensus on the modality of radiation, dose, or the adequate time for administration. It could reasonably be assumed that CRT could be more beneficial on OS than other adjuvant treatments with less-toxic effects due to the low radiation doses used [42].

However, based on these findings the ASCO guidelines have [7], the role of chemo-radiotherapy remains unclear and this suggests that its use should be limited to patients with eCCAs with R1 resection or other high-risk factors.

\subsection{Targeted Therapy}

Early studies on the genetic pathophysiology of CCAs focused on the elucidation of the carcinogenic role of single genes, often found mutated in other malignancies, or genes affected by copy number alterations [43]. In recent years, due to the advent of next-generation sequencing technology, a series of complex molecular events, their interactions, and their relationships with risk factors and causative events were revealed in biliary cancers. Among them, mutations in the genes of isocitrate dehydrogenases (IDH, isoforms 1 and 2), fusions of the fibroblast growth factor receptor 2 (FGFR2), and mutations of chromatin-remodeling genes, such as AT-rich interaction domain 1A (ARID1A), protein poly-bromo1 (PBRM1), and BRCA1-associated protein 1 (BAP1), were detected [8]. Target treatments were extensively discussed in very recent reviews [8,31,43].

Isocitrate dehydrogenase (IDH, isoforms 1 and 2) is involved in glucose metabolism, and mutation of these genes leads to the accumulation of the oncometabolite D-2hydroxyglutarate (2-HG) and resultant epigenetic dysregulation and aberrant cell signalling. Mutations in IDH1 are found in $10 \%-25 \%$ of patients with advanced CCAs [44]. Ivosidenib (AG-120), an oral inhibitor of IDH1, was administered to patients with mutated advanced CCAs who were ineligible for resection and had disease progression following 1 to 2 prior systemic therapies [44]. Ivosidenib prolonged median PFS compared to the effect of placebo ( 2.7 vs. 1.4 months, HR $0.37 ; p<0.001$ ), there was a numerical improvement in median OS (10.8 vs. 9.7 months, HR 0.69; $p=0.06)$, and DCR nearly doubled (53\% vs. $28 \%$ for placebo) [44]. Other IDH selective inhibitors, such as IDH305 (IDH1 inhibitor), enasidenib (IDH2 inhibitor), and AG-881 (IDH1 and 2 inhibitor), are still under study [8,45].

FGFR2 gene rearrangements code for constitutively activated fusion products, resulting in aberrant mitogenic signalling with dysregulation of cell proliferation, survival, and angiogenesis. FGFR2 alterations have been reported in $13 \%$ to $17 \%$ of patients with CCAs [31,43]. Multiple oral tyrosine kinase inhibitors (TKIs) targeting FGFR were tested in patients with advanced CCAs, who presented FGFR gene fusions or other alterations and progressed after prior first-line therapy. Infigratinib (BGJ398) [46], pemigatinib (INCB054828) [47], derazantinib (ARQ 087) [48], and TAS-120 [49] demonstrated ORRs of 31\%,36\%, 21\%, and 25\%, respectively, with a median PFS of 6.8 months for infigratinib, 6.9 months for pemigatinib, 5.7 months for derazantinib (data from the study with TAS-120 are not yet mature), an OS of 12.5 months for infigratinib and 21.1 months for pemigatinib (for Derezantinib and TAS-120, OS is not yet reached), and a DCR of approximately $80 \%$. The ongoing Phase III trials will compare some of these TKIs to GemCis for first-line treatment of advanced CCAs [31,43].

HER2 (or ErbB2) alterations are found in 5.7\% to $7.6 \%$ of all CCAs, and in 10\%-32\% of iCCAs [8,31]. The combination of trastuzumab and pertuzumab in the MyPathway trial (NCT02091141) [47], resulted in disease control in six out of eight HER2-amplified/overexpressed patients with a BTC, while two of the nine patients responded to neratinib in the SUMMIT trial (NCT01953926) [50]. Safety and activity were shown with the panHER inhibitor varlitinib combined with CT (RR 27\%, DCR 70\%) [51], while ongoing trials are evaluating afatinib (NCT02451553) and trastuzumab-emtansine (NCT02999672) [31].

VEGF was found to be overexpressed in 53.8\% of iCCAs and 59.2\% of eCCAs [43]; different associations between bevacizumab and CT and multikinase inhibitors, such as vandetanib 
and regorafenib [52], were tested and have shown some activity; ramucirumab is also currently under investigation $[8,31,43]$.

Activation of missense BRAF mutations is reported in $11 \%-22 \%$ of CCAs, depending on the studies' population [53,54]. Vemurafenib, in combination with an MEK inhibitor, appeared to be promising in cancers harboring BRAF V600 mutations [31]. Selumetinib, an inhibitor of MEK1/2 proteins, supported stable disease alone or in combination with chemotherapy. An ongoing Phase II trial is evaluating the combination of solumetinib with gemcitabine vs. gemcitabine alone. Furthermore, other promising MEK inhibitors, including refametinib, trametinib, and MEK162, are under investigation in several clinical trials [8].

Unsatisfactory results derived from the use of MET inhibitors such as cabozantinib (abnormal MET activation has been found in $12 \%-58 \%$ of iCCAs) PI3K/AKT/mTOR inhibitors showed exiguous responses despite $12.5 \%$ of gallbladder cancers displaying activated mutations of PIK3CA. The ongoing Phase II STARTRK-2 trial is investigating entrectinib in patients with solid tumours harboring NTRK, ROS1, or ALK gene rearrangements/fusions, including those with CCAs [55].

Hypermutated BTCs characterized by increased expression of PD1/PD-L1 have a poor prognosis. Less than $1 \%$ of patients had high microsatellite instability (MSI), and the trials with immune-checkpoint inhibitors showed infrequent responses in the microsatellite stable tumours [31]. Immunotherapy was tested in BTC patients with some partial response and disease control, with a 12-month OS of 33\% [32].

In all subtypes, clinical studies with PD-1 and PD-L1 blockade agents have shown ORRs in the 5\%-20\% range and meaningful disease control [56-61]. Unfortunately, at the moment, PD-L1 expression, MSI, mismatch repair deficiencies, and tumour mutational burden are not available as predictive biomarkers [32]. To improve the immune response, the combination of CT (TOPAZ-1, IMMUCHEC, NCT03111732, NCT03101566, NCT04027764, NCT03982680, NCT04003636), RT (CORRECT trial), locoregional procedures (NCT02821754), targeted agents, and new immunotherapy effectors are under investigation [31,62].

Promising targets for potentially interesting inhibitors are the proteins of the JAK/STAT, Wnt $/ \beta$-catenin, Hedgehog and Notch signalling pathways, inhibitors that target mutations in chromatin-remodelling genes, such as ARID1A, PBRM1, and BAP1, and inhibitors of cancer-associated fibroblasts [8]. New drugs, aimed at simultaneously targeting several cell types that are critically involved in the development and progression of CCA, are in development.

A curious observational study, published in JAMA Oncology, showed that the use of aspirin in patients with BTC was associated with a decreased risk of death (HR of 0.63 for gallbladder cancer and of 0.71 for CCA) which may be due to the drug's inhibition of platelet aggregation slowing the spread of metastatic cancer cells. The researchers noted that incidental aspirin users who had no prior history of using the drug had a greater survival benefit from postdiagnosis aspirin use than those who were prevalent users, but they did not have an explanation [63]. One hypothesis is that tumours that developed during aspirin consumption were less susceptible to its beneficial function.

\subsection{Locoregional Treatments}

Considering that most patients present with unresectable advanced disease confined to the liver at diagnosis, liver-directed therapy could offer disease control or, even better, a primary mass volume reduction with the maintenance of adequate liver function. The liver's dual blood supply preferentially delivers high doses of chemotherapeutic agents to the hepatic artery, which supplies nearly all of the tumour's blood flow, while blood delivered by the portal vein maintains the health of the non-neoplastic liver parenchyma. Because the liver clears the chemotherapeutic agent via first-pass metabolism, locoregional approaches could diminish the systemic toxic effects of chemotherapy. A single-institution, Phase II clinical trial [64] investigated hepatic arterial infusion (HAI) of high-dose chemotherapy combined with first-line systemic chemotherapy in patients with unresectable intrahepatic CCA. Via HAI, high-dose floxuridine, a precursor of fluorouracil chemotherapy, was delivered directly into the liver, while systemic GemOx chemotherapy was 
administered. A response rate of $58 \%$ and an excellent disease control rate of $84 \%$ in the primary tumour at 6 months was achieved. Four patients underwent resection, and 1 patient had a complete pathologic response. The median PFS was 11.8 months and the median OS was 25.0 months, with a 1-year OS rate of $89.5 \%$. A response in the dominant liver mass helped to prevent liver-related complications, such as biliary obstruction and portal vein occlusion, which are often associated with interruption of systemic therapy. This finding suggests that longer survival was correlated with the response of the primary tumour. Interestingly the subgroup analysis showed significant improvement in survival in patients with IDH1/2 mutated tumours (2-year OS 90\%, 95\% CI, 73\%-99\%) vs. wild-type tumours (2-year OS 33\%, 95\% CI, 18\%-63\%) [64].

In another Phase II study, the yttrium-90 microspheres (MISPHEC) trial [65], the technique of radioembolization, also known as selective internal radiotherapy (SIRT), was used in locally advanced iCCA in combination with systemic therapy with the GemCis regimen. Radiolabeled microspheres were administered via the hepatic arteries, delivering radiotherapy when reaching the tumour vasculature. The results showed PFS of 14 months and a median OS of 22 months, with an increased number of downstaged tumours and chance of surgery [41]. In the SIRCCA phase II trial, SIRT followed by CIS-GEM chemotherapy vs. CIS-GEM chemotherapy alone as first-line treatment of patients with unresectable intrahepatic CCA is currently randomising patients with unresectable CCA to either chemotherapy alone or resin-microsphere SIRT followed by chemotherapy, and a study comparing SIRT with chemoembolization is ongoing [66].

\section{Discussion}

BTCs are infrequent cancers that have been poorly studied in the past decades and have few treatment options, low response rates, and bad prognosis. Their rarity and the difficulty of obtaining good diagnostic samples make the effective development of translational research in this field significantly difficult. One of the most important steps forward will be the definition of the true value of some of the risk factors (such as R1 ore node positivity), and to correctly use them as stratification factors to pre-plan a correct statistical analysis [22] and for tailored treatment strategies. Moreover, valid and specific biomarkers are needed to select patients who are more likely to benefit from specific adjuvant strategies. Last but not least, there is a need for in-depth translational research to understand the mechanisms of resistance and disease recurrence. In this regard, an appropriate study design is crucial, where new Phase III randomised studies, comparing experimental arms with an active (non-observational) control arm (currently: capecitabine), need to be initiated after careful thoughts.

Although complete surgical resection (R0) remains the most effective approach for prolonging survival, disease recurrence is not uncommon. Furthermore, even if surgery could be technically performed, this could not always be contemplated due to patient comorbidities. The development of interventional techniques with lower morbidity is therefore essential to prolong survival in that population. Locoregional therapies should offer an important next step to improve survival by controlling local disease progression. As a result, some groups are experimenting with modifications to photoactive compounds in PDT, probe modifications in RFA, and combinations of locoregional therapy and concurrent chemotherapy [4]. Some progress has also been made in first-line therapies. The triple therapy with gemcitabine-cisplatin plus nab-paclitaxel resulted in a higher median PFS, OS, and RR than the combination therapies reported previously [24]. Other combinations are under investigation and have shown promising results.

Moreover, after tumour progression, there is no clear evidence of whether a combination therapy can be superior to a single targeted/toxic agent. However, since the overall quantity and quality of data regarding second-line therapy is poor and considering the risk of bias in comparisons between the observation studies, prospective randomized studies are strongly recommended [37]. Due to the rarity of advanced BTC patients, future multi-institutional clinical trials should promote good-sized studies that focus on stratifying patients on the basis of their anatomic subtype and genetic drivers in order to predict response to the new therapeutic options and the prognosis. 
Despite the considerable progress that has been made in molecularly profiling BTCs, knowledge on the cause-and-effect relationship between the molecular changes and transformation of normal biliary epithelium to invasive malignancy, and our understanding of the interactions among the various signalling pathways and components that produce the cancer cell phenotypes, are still lacking.

At the top of the list is the definition of some prognostic tools for selecting patients who could benefit more from adjuvant chemotherapy or radiotherapy or the combination of both. For example, we need some lines about which therapy is preferred based on the volume, extension of disease, the presence of jaundice or other symptoms, age, performance status, serum carcinoembryonic antigen and CA19-9 levels and liver function. In addition, for the selection of patients to be candidates for a first-line treatment, we must evaluate the recurrence time, the primary surgery, the extent and locations of the metastatic disease and whether it may be susceptible to locoregional therapies, comorbidities and life expectancies. Unfortunately, no studies have yet established clear selection criteria and we hope this will be the topic of the next work.

\section{Conclusions}

The therapeutic landscape in BTC has expanded considerably in recent years after being nearly forgotten for a few decades. Combined therapy with chemotherapy, locoregional treatment and immunotherapy are promising strategies. The knowledge of the biology of BTC is still limited compared to that of other solid cancers, but the available data on target therapies have added hopes for the future management of hepatobiliary cancers and will likely continue to improve patient outcomes. Results from ongoing clinical trials are eagerly awaited to further elucidate the optimal management of this aggressive malignancy.

Author Contributions: Conceptualization, A.Z. and M.A.H.; resources, A.Z.; investigation, E.O.; writing-original draft preparation, E.O.; writing—review and editing, A.Z., M.A.H., and E.O.; visualization, E.O.; supervision, A.Z. All authors have read and agreed to the published version of the manuscript.

Funding: This research received no external funding.

Conflicts of Interest: The authors declare no conflict of interest.

\section{References}

1. Banales, J.M.; Cardinale, V.; Carpino, G.; Marzioni, M.; Andersen, J.B.; Invernizzi, P.; Lind, G.E.; Folseraas, T.; Forbes, S.J.; Fouassier, L.; et al. Expert consensus document: Cholangiocarcinoma: Current knowledge and future perspectives consensus statement from the European Network for the Study of Cholangiocarcinoma (ENS-CCA). Nat. Rev. Gastroenterol. Hepatol. 2016, 13, 261-280. [CrossRef] [PubMed]

2. Hundal, R.; Shaffer, E.A. Gallbladder cancer: Epidemiology and outcome. Clin. Epidemiol. 2014, 6, 99-109. [CrossRef] [PubMed]

3. Lazcano-Ponce, E.C.; Miquel, J.F.; Muñoz, N.; Herrero, R.; Ferrecio, C.; Wistuba, I.I.; Alonso de Ruiz, P.; Aristi Urista, G.; Nervi, F. Epidemiology and molecular pathology of gallbladder cancer. CA Cancer J. Clin. 2001, 51, 349-364. [CrossRef] [PubMed]

4. Altekruse, S.F.; Devesa, S.S.; Dickie, L.A.; McGlynn, K.A.; Kleiner, D.E. Histological classification of liver and intrahepatic bile duct cancers in SEER registries. J. Regist. Manag. 2011, 38, 201-205.

5. Bergquist, A.; von Seth, E. Epidemiology of cholangiocarcinoma. Best Pract. Res. Clin. Gastroenterol. 2015, 29, 221-232. [CrossRef]

6. American Cancer Society: Cancer Statistic Center, Estimates 2019. Available online: https://cancerstatisticsce nter.cancer.org/module/BmVYeqHT (accessed on 17 March 2020).

7. Shroff, R.T.; Kennedy, E.B.; Bachini, M.; Bekaii-Saab, T.; Crane, C.; Edeline, J.; El-Khoueiry, A.; Feng, M.; Katz, M.H.G.; Primrose, J.; et al. Adjuvant Therapy for Resected Biliary Tract Cancer: ASCO Clinical Practice Guideline. J. Clin. Oncol. 2019, 37, 1015-1027. [CrossRef]

8. Simile, M.M.; Bagella, P.; Vidili, G.; Spanu, A.; Manetti, R.; Seddaiu, M.A.; Babudieri, S.; Madeddu, G.; Serra, P.A.; Altana, M.; et al. Targeted Therapies in Cholangiocarcinoma: Emerging Evidence from Clinical Trials. Medicina 2019, 55, 42. [CrossRef] 
9. Hemming, A.W. Biliary Tract and Primary Liver Tumors: Who, What, and Why? Surg. Oncol. Clin. N. Am. 2019, 28, 519-538. [CrossRef]

10. Sangchan, A.; Kongkasame, W.; Pugkhem, A.; Jenwitheesuk, K.; Mairiang, P. Efficacy of metal and plastic stents in unresectable complex hilar cholangiocarcinoma: A randomized controlled trial. Gastrointest. Endosc. 2012, 76, 93-99. [CrossRef]

11. Green, B.L.; House, M.G. Nonsurgical Approaches to Treat Biliary Tract and Liver Tumors. Surg. Oncol. Clin. N. Am. 2019, 28, 573-586. [CrossRef]

12. Valle, J.; Wasan, H.; Palmer, D.H.; Cunningham, D.; Anthoney, A.; Maraveyas, A.; Madhusudan, S.; Iveson, T.; Hughes, S.; Pereira, S.P.; et al. Cisplatin plus gemcitabine versus gemcitabine for biliary tract cancer. N. Engl. J. Med. 2010, 362, 1273-1281. [CrossRef] [PubMed]

13. Ebata, T.; Hirano, S.; Konishi, M.; Uesaka, K.; Tsuchiya, Y.; Ohtsuka, M.; Kaneoka, Y.; Yamamoto, M.; Ambo, Y.; Shimizu, Y.; et al. Randomized clinical trial of adjuvant gemcitabine chemotherapy versus observation in resected bile duct cancer. Br. J. Surg. 2018, 105, 192-202. [CrossRef] [PubMed]

14. Edeline, J.; Benabdelghani, M.; Bertaut, A.; Watelet, J.; Hammel, P.; Joly, J.P.; Boudjema, K.; Fartoux, L.; Bouhier-Leporrier, K.; Jouve, J.L.; et al. Gemcitabine and Oxaliplatin Chemotherapy or Surveillance in Resected Biliary Tract Cancer (PRODIGE 12-ACCORD 18-UNICANCER GI): A Randomized Phase III Study. J. Clin. Oncol. 2019, 37, 658-667. [CrossRef] [PubMed]

15. Primrose, J.N.; Fox, R.P.; Palmer, D.H.; Malik, H.Z.; Prasad, R.; Mirza, D.; Anthony, A.; Corrie, P.; Falk, S.; Finch-Jones, M.; et al. Capecitabine compared with observation in resected biliary tract cancer (BILCAP): A randomised, controlled, multicentre, phase 3 study. Lancet Oncol. 2019, 20, 663-673. [CrossRef]

16. Kobayashi, S.; Nagano, H.; Tomokuni, A.; Gotoh, K.; Sakai, D.; Hatano, E.; Seo, S.; Terajima, H.; Uchida, Y.; Ajiki, T.; et al. A Prospective, Randomized Phase II Study of Adjuvant Gemcitabine Versus S-1 After Major Hepatectomy for Biliary Tract Cancer (KHBO 1208): Kansai Hepato-Biliary Oncology Group. Ann. Surg. 2019, 270, 230-237. [CrossRef] [PubMed]

17. Nakachi, K.; Konishi, M.; Ikeda, M.; Mizusawa, J.; Eba, J.; Okusaka, T.; Ishii, H.; Fukuda, H.; Furuse, J.; Hepatobiliary and Pancreatic Oncology Group of the Japan Clinical Oncology Group. A randomized Phase III trial of adjuvant S-1 therapy vs. observation alone in resected biliary tract cancer: Japan Clinical Oncology Group Study (JCOG1202, ASCOT). Jpn. J. Clin. Oncol. 2018, 48, 392-395. [CrossRef] [PubMed]

18. Stein, A.; Arnold, D.; Bridgewater, J.; Goldstein, D.; Jensen, L.H.; Klümpen, H.J.; Lohse, A.W.; Nashan, B.; Primrose, J.; Schrum, S.; et al. Adjuvant chemotherapy with gemcitabine and cisplatin compared to observation after curative intent resection of cholangiocarcinoma and muscle invasive gallbladder carcinoma (ACTICCA-1 trial)_A randomized, multidisciplinary, multinational phase III trial. BMC Cancer 2015, 15, 564. [CrossRef]

19. Messina, C.; Merz, V.; Frisinghelli, M.; Trentin, C.; Grego, E.; Veccia, A.; Salati, M.; Messina, M.; Carnaghi, C.; Caffo, O. Adjuvant chemotherapy in resected bile duct cancer: A systematic review and meta-analysis of randomized trials. Crit. Rev. Oncol. Hematol. 2019, 143, 124-129. [CrossRef]

20. Caparica, R.; Bruzzone, M.; Hachem, G.E.; Ceppi, M.; Lambertini, M.; Glasberg, J.; de Azambuja, E.; Van Laethem, J.L.; Hendlisz, A. Adjuvant chemotherapy in biliary tract cancer patients: A systematic review and meta-analysis of randomized controlled trials. Crit. Rev. Oncol. Hematol. 2020, 149, 102940. [CrossRef]

21. Lamarca, A.; Palmer, D.H.; Wasan, H.S.; Ross, P.J.; Ma, Y.T.; Arora, A.; Falk, S.; Gillmore, R.; Wadsley, J.; Patel, K.; et al. ABC-06 | A randomised phase III, multi-centre, open-label study of active symptom control (ASC) alone or ASC with oxaliplatin/5-FU chemotherapy (ASC + mFOLFOX) for patients (pts) with locally advanced/metastatic biliary tract cancers $(\mathrm{ABC})$ previously-treated with cisplatin/gemcitabine (CisGem) chemotherapy. J. Clin. Oncol. 2019, 37, 4003. [CrossRef]

22. Lamarca, A.; Edeline, J.; McNamara, M.G.; Hubner, R.A.; Nagino, M.; Bridgewater, J.; Primrose, J.; Valle, J.W. Current standards and future perspectives in adjuvant treatment for biliary tract cancers. Cancer Treat. Rev. 2020, 84, 101936. [CrossRef] [PubMed]

23. Malka, D.; Edeline, J. Adjuvant capecitabine in biliary tract cancer: A standard option? Lancet Oncol 2019, 20, 606-608. [CrossRef]

24. Roth, M.T.; Goff, L.W. Gemcitabine, Cisplatin, and nab-Paclitaxel for Patients With Advanced Biliary Tract Cancer: Closing the GAP. JAMA Oncol. 2019, 5, 831-832. [CrossRef] [PubMed] 
25. Shroff, R.T.; Javle, M.M.; Xiao, L.; Kaseb, A.O.; Varadhachary, G.R.; Wolff, R.A.; Raghav, K.P.S.; Iwasaki, M.; Masci, P.; Ramanathan, R.K.; et al. Gemcitabine, Cisplatin, and nab-Paclitaxel for the Treatment of Advanced Biliary Tract Cancers: A Phase 2 Clinical Trial. JAMA Oncol. 2019, 5, 824-830. [CrossRef]

26. Conroy, T.; Desseigne, F.; Ychou, M.; Bouché, O.; Guimbaud, R.; Bécouarn, Y.; Adenis, A.; Raoul, J.L.; Gourgou-Bourgade, S.; de la Fouchardière, C.; et al. FOLFIRINOX versus gemcitabine for metastatic pancreatic cancer. N. Engl. J. Med. 2011, 364, 1817-1825. [CrossRef]

27. Rauthan, A.; Patil, P. Modified FOLFIRINOX regimen in advanced biliary tract adenocarcinoma. J. Clin. Oncol. 2017, 35, 484. [CrossRef]

28. Ulusakarya, A.; Abdou, W.K.J.; Karaboué, A.; Haydar, M.; Krimi, S.; Gumus, Y.; Almohamad, W.; Goldschmidt, E.; Biondani, P.; Morère, J.F. FOLFIRINOX as A First-Line Chemotherapy for Patients (pts) with Advanced Biliary Tract Cancer (BTC) | OncologyPRO. Available online: https://oncologypro.esmo.org/meeting-resources/esmo-2018-congres s/FOLFIRINOX-as-a-first-line-chemotherapy-for-patients-pts-with-advanced-biliary-tract-cancer-BTC (accessed on 21 October 2018).

29. Phelip, J.M.; Edeline, J.; Blanc, J.F.; Barbier, E.; Michel, P.; Bourgeois, V.; Neuzillet, C.; Malka, D.; Manfredi, S.; Desrame, J. Modified FOLFIRINOX versus CisGem first-line chemotherapy for locally advanced non resectable or metastatic biliary tract cancer (AMEBICA)-PRODIGE 38: Study protocol for a randomized controlled multicenter phase II/III study. Dig. Liver Dis. 2019, 51, 318-320. [CrossRef]

30. Perkhofer, L.; Berger, A.W.; Beutel, A.K.; Gallmeier, E.; Angermeier, S.; Fischer von Weikersthal, L.; Goetze, T.O.; Muche, R.; Seufferlein, T.; Ettrich, T.J. Nal-IRI with 5-fluorouracil (5-FU) and leucovorin or gemcitabine plus cisplatin in advanced biliary tract cancer-The NIFE trial (AIO-YMO HEP-0315) an open label, non-comparative, randomized, multicenter phase II study. BMC Cancer 2019, 19, 990. [CrossRef]

31. Filippi, R.; Lombardi, P.; Quarà, V.; Fenocchio, E.; Aimar, G.; Milanesio, M.; Leone, F.; Aglietta, M. Pharmacotherapeutic options for biliary tract cancer: Current standard of care and new perspectives. Expert Opin. Pharm. 2019, 20, 2121-2137. [CrossRef]

32. Tella, S.H.; Kommalapati, A.; Borad, M.J.; Mahipal, A. Second-line therapies in advanced biliary tract cancers. Lancet Oncol. 2020, 21, e29-e41. [CrossRef]

33. Zheng, Y.; Tu, X.; Zhao, P.; Jiang, W.; Liu, L.; Tong, Z.; Zhang, H.; Yan, C.; Fang, W.; Wang, W. A randomised phase II study of second-line XELIRI regimen versus irinotecan monotherapy in advanced biliary tract cancer patients progressed on gemcitabine and cisplatin. Br. J. Cancer 2018, 119, 291-295. [CrossRef] [PubMed]

34. Guion-Dusserre, J.F.; Lorgis, V.; Vincent, J.; Bengrine, L.; Ghiringhelli, F. FOLFIRI plus bevacizumab as a second-line therapy for metastatic intrahepatic cholangiocarcinoma. World J. Gastroenterol. 2015, 21, 2096-2101. [CrossRef] [PubMed]

35. Sebbagh, S.; Roux, J.; Dreyer, C.; Neuzillet, C.; de Gramont, A.; Orbegoso, C.; Hentic, O.; Hammel, P.; Raymond, E.; André, T.; et al. Efficacy of a sequential treatment strategy with GEMOX-based followed by FOLFIRI-based chemotherapy in advanced biliary tract cancers. Acta Oncol. 2016, 55, 1168-1174. [CrossRef] [PubMed]

36. Chakrabarti, S.; Zemla, T.J.; Ahn, D.H.; Ou, F.S.; Fruth, B.; Borad, M.J.; Hartgers, M.L.; Wessling, J.; Walkes, R.L.; Alberts, S.R.; et al. Phase II Trial of Trifluridine/Tipiracil in Patients with Advanced, Refractory Biliary Tract Carcinoma. Oncologist 2019. [CrossRef] [PubMed]

37. Ying, J.; Chen, J. Combination versus mono-therapy as salvage treatment for advanced biliary tract cancer: A comprehensive meta-analysis of published data. Crit. Rev. Oncol. Hematol. 2019, 139, 134-142. [CrossRef] [PubMed]

38. Valle, J.W.; Borbath, I.; Khan, S.A.; Huguet, F.; Gruenberger, T.; Arnold, D. Clinical practice guidelines of the European Society for Medical Oncology (ESMO) for the management ofbiliary tract cancer. Ann. Oncol. 2016, 27 (Suppl. 5), v28-v37. [CrossRef]

39. Tao, R.; Krishnan, S.; Bhosale, P.R.; Javle, M.M.; Aloia, T.A.; Shroff, R.T.; Kaseb, A.O.; Bishop, A.J.; Swanick, C.W.; Koay, E.J.; et al. Ablative Radiotherapy Doses Lead to a Substantial Prolongation of Survival in Patients With Inoperable Intrahepatic Cholangiocarcinoma: A Retrospective Dose Response Analysis. J. Clin. Oncol. 2016, 34, 219-226. [CrossRef]

40. Ren, B.; Guo, Q.; Yang, Y.; Liu, L.; Wei, S.; Chen, W.; Tian, Y. A meta-analysis of the efficacy of postoperative adjuvant radiotherapy versus no radiotherapy for extrahepatic cholangiocarcinoma and gallbladder carcinoma. Radiat. Oncol. 2020, 15, 15. [CrossRef] 
41. Manterola, C.; Duque, G.; Grande, L.; de Aretxabala, X.; Conejeros, R.; Otzen, T.; García, N. A systematic review of the effectiveness of adjuvant therapy for patients with gallbladder cancer. HPB 2019, 21, 1427-1435. [CrossRef]

42. Ben-Josef, E.; Guthrie, K.A.; El-Khoueiry, A.B.; Corless, C.L.; Zalupski, M.M.; Lowy, A.M.; Thomas, C.R., Jr.; Alberts, S.R.; Dawson, L.A.; Micetich, K.C.; et al. SWOG S0809: A Phase II Intergroup Trial of Adjuvant Capecitabine and Gemcitabine Followed by Radiotherapy and Concurrent Capecitabine in Extrahepatic Cholangiocarcinoma and Gallbladder Carcinoma. J. Clin. Oncol. 2015, 33, 2617-2622. [CrossRef]

43. Updates on Treating Intrahepatic Cholangiocarcinoma. Available online: https://www.medscape.org/viewa rticle/919827 (accessed on 25 October 2019).

44. Abou-Alfa, G.K.; Macarulla Mercade, T.; Javle, M.; Kelley, R.K.; Lubner, S.; Adeva, J.; Cleary, J.M.; Catenacci, D.V.; Borad, M.J.; Bridgewater, J.A.; et al. ClarIDHy: A Global, Phase 3, Randomized, Double-Blind Study of Ivosidenib (IVO) vs. Placebo in Patients with Advanced Cholangiocarcinoma (CC) with a ... | OncologyPRO. Available online: https:/oncologypro.esmo.org/meeting-resources/esmo-2019-c ongress/ClarIDHy-A-global-phase-3-randomized-double-blind-study-of-ivosidenib-IVO-vs-placebo-i n-patients-with-advanced-cholangiocarcinoma-CC-with-an-isocitrate-dehydrogenase-1-IDH1-mutation (accessed on 30 September 2019).

45. Phase I Study of BAY1436032 in IDH1-mutant Advanced Solid Tumors—Full Text View-ClinicalTrials.gov. Available online: https://clinicaltrials.gov/ct2/show/NCT02746081 (accessed on 16 April 2020).

46. Javle, M.; Lowery, M.; Shroff, R.T.; Weiss, K.H.; Springfeld, C.; Borad, M.J.; Ramanathan, R.K.; Goyal, L.; Sadeghi, S.; Macarulla, T.; et al. Phase II Study of BGJ398 in Patients With FGFR-Altered Advanced Cholangiocarcinoma. J. Clin. Oncol. 2018, 36, 276-282. [CrossRef] [PubMed]

47. Vogel, A.; Sahai, V.; Hollebecque, A.; Vaccaro, G.; Melisi, D.; Al-Rajabi, R.; Paulson, A.S.; Borad, M.J.; Gallinson, D.; Murphy, A.G.; et al. LBA40-FIGHT-202: A phase II study of pemigatinib in patients (pts) with previously treated locally advanced or metastatic cholangiocarcinoma (CCA). Ann. Oncol. 2019, 30 , v876. [CrossRef]

48. Voss, M.H.; Hierro, C.; Heist, R.S.; Cleary, J.M.; Meric-Bernstam, F.; Tabernero, J.; Janku, F.; Gandhi, L.; Iafrate, A.J.; Borger, D.R.; et al. A Phase I, Open-Label, Multicenter, Dose-escalation Study of the Oral Selective FGFR Inhibitor Debio 1347 in Patients with Advanced Solid Tumors Harboring FGFR Gene Alterations. Clin. Cancer Res. 2019, 25, 2699-2707. [CrossRef]

49. Meric-Bernstam, F.; Arkenau, H.; Tran, B.; Bahleda, R.; Kelley, R.; Hierro, C.; Ahn, D.; Zhu, A.; Javle, M.; Winkler, R.; et al. Efficacy of TAS-120, an irreversible fibroblast growth factor receptor (FGFR) inhibitor, in cholangiocarcinoma patients with FGFR pathway alterations who were previously treated with chemotherapy and other FGFR inhibitors. Ann. Oncol. 2018, 29 (Suppl. 5), v100. [CrossRef]

50. Hyman, D.M.; Piha-Paul, S.A.; Won, H.; Rodon, J.; Saura, C.; Shapiro, G.I.; Juric, D.; Quinn, D.I.; Moreno, V.; Doger, B.; et al. HER kinase inhibition in patients with HER2- and HER3-mutant cancers. Nature 2018, 554, 189-194. [CrossRef]

51. Tan, A.C.; Oh, D.-Y.; Chao, Y.; Hsieh, C.-Y.; Chang, W.-L.; Isanto, F.; Chen, Y.-C.; McHale, M.; Lindmark, B.; $\mathrm{Ng}$, M.C.H. Efficacy and safety of varlitinib, a reversible pan-HER tyrosine kinase inhibitor, in combination with platinum-based regimens in biliary tract cancers: A pooled analysis from three phase I studies. J. Clin. Oncol. 2019, 37, 331. [CrossRef]

52. Sun, W.; Patel, A.; Normolle, D.; Patel, K.; Ohr, J.; Lee, J.J.; Bahary, N.; Chu, E.; Streeter, N.; Drummond, S. A phase 2 trial of regorafenib as a single agent in patients with chemotherapy-refractory, advanced, and metastatic biliary tract adenocarcinoma. Cancer 2019, 125, 902-909. [CrossRef]

53. Tannapfel, A.; Sommerer, F.; Benicke, M.; Katalinic, A.; Uhlmann, D.; Witzigmann, H.; Hauss, J.; Wittekind, C. Mutations of the BRAF gene in cholangiocarcinoma but not in hepatocellular carcinoma. Gut 2003, 52, 706-712. [CrossRef]

54. Wardell, C.P.; Fujita, M.; Yamada, T.; Simbolo, M.; Fassan, M.; Karlic, R.; Polak, P.; Kim, J.; Hatanaka, Y.; Maejima, K.; et al. Genomic characterization of biliary tract cancers identifies driver genes and predisposing mutations. J. Hepatol. 2018, 68, 959-969. [CrossRef]

55. Basket Study of Entrectinib (RXDX-101) for the Treatment of Patients With Solid Tumors Harboring NTRK 1/2/3 (Trk A/B/C), ROS1, or ALK Gene Rearrangements (Fusions)—Full Text View—ClinicalTrials.gov. Available online: https://linicaltrials.gov/ct2/show/NCT02568267 (accessed on 1 May 2020). 
56. Kim, R.D.; Chung, V.; Alese, O.B.; El-Rayes, B.F.; Li, D.; Al-Toubah, T.E.; Schell, M.J.; Zhou, J.M.; Mahipal, A.; Kim, B.H.; et al. A Phase 2 Multi-institutional Study of Nivolumab for Patients With Advanced Refractory Biliary Tract Cancer. JAMA Oncol. 2020. [CrossRef]

57. Jakubowski, C.D.; Azad, N.S. Immune checkpoint inhibitor therapy in biliary tract cancer (cholangiocarcinoma). Chin. Clin. Oncol. 2020, 9, 2. [CrossRef]

58. Sun, D.; Ma, J.; Wang, J.; Han, C.; Qian, Y.; Chen, G.; Li, X.; Zhang, J.; Cui, P.; Du, W.; et al. Anti-PD-1 therapy combined with chemotherapy in patients with advanced biliary tract cancer. Cancer Immunol. Immunother. 2019, 68, 1527-1535. [CrossRef] [PubMed]

59. Piha-Paul, S.A.; Oh, D.Y.; Ueno, M.; Malka, D.; Chung, H.C.; Nagrial, A.; Kelley, R.K.; Ros, W.; Italiano, A.; Nakagawa, K.; et al. Efficacy and safety of pembrolizumab for the treatment of advanced biliary cancer: Results from the KEYNOTE-158 and KEYNOTE-028 studies. Int. J. Cancer 2020. [CrossRef] [PubMed]

60. Bang, Y.-J.; Ueno, M.; Malka, D.; Chung, H.C.; Nagrial, A.; Kelley, R.K.; Piha-Paul, S.A.; Ros, W.; Italiano, A.; Nakagawa, K.; et al. Pembrolizumab (pembro) for advanced biliary adenocarcinoma: Results from the KEYNOTE-028 (KN028) and KEYNOTE-158 (KN158) basket studies. J. Clin. Oncol. 2019. [CrossRef]

61. Ioka, T.; Ueno, M.; Oh, D.-Y.; Fujiwara, Y.; Chen, J.-S.; Doki, Y.; Mizuno, N.; Park, K.; Asagi, A.; Hayama, M.; et al. Evaluation of safety and tolerability of durvalumab (D) with or without tremelimumab (T) in patients (pts) with biliary tract cancer (BTC). J. Clin. Oncol. 2019. [CrossRef]

62. Pembrolizumab (MK-3475) Plus Gemcitabine/Cisplatin Versus Placebo Plus Gemcitabine/Cisplatin for First-Line Advanced and/or Unresectable Biliary Tract Carcinoma (BTC) (MK-3475-966/KEYNOTE-966)—Full Text View—ClinicalTrials.gov. Available online: https://www.google.com/search?ei=ImmxXqfpOIywrgSh2aqACw\&q=keyn ote+966\&oq=keybote+966\&gs_lcp=ChNtb2JpbGUtZ3dzLXdpei1zZXJwEAMyBAgAEA0yBggAEBYQHjoECAAQ RzoCCCk6AggAOgUIABCDAToECAAQAzoECAAQCjoECCkQEzoICC4QgwEQkwI6AgguOgQIABBDUJESWI VKYJpMaABwAXgDgAG_A4gB1CKSAQsxMi4xNi4xLjIuMZgBAKABAbABDw\&sclient=mobile-gws-wiz-serp (accessed on 7 May 2020).

63. Jackson, S.S.; Pfeiffer, R.M.; Liu, Z.; Anderson, L.A.; Tsai, H.T.; Gadalla, S.M.; Koshiol, J. Association Between Aspirin Use and Biliary Tract Cancer Survival. JAMA Oncol. 2019. [CrossRef] [PubMed]

64. Cercek, A.; Boerner, T.; Tan, B.R.; Chou, J.F.; Gönen, M.; Boucher, T.M.; Hauser, H.F.; Do, R.K.G.; Lowery, M.A.; Harding, J.J.; et al. Assessment of Hepatic Arterial Infusion of Floxuridine in Combination With Systemic Gemcitabine and Oxaliplatin in Patients With Unresectable Intrahepatic Cholangiocarcinoma: A Phase 2 Clinical Trial. JAMA Oncol. 2019, 6, 60-67. [CrossRef]

65. Edeline, J.; Touchefeu, Y.; Guiu, B.; Farge, O.; Tougeron, D.; Baumgaertner, I.; Ayav, A.; Campillo-Gimenez, B.; Beuzit, L.; Pracht, M.; et al. Radioembolization Plus Chemotherapy for First-line Treatment of Locally Advanced Intrahepatic Cholangiocarcinoma: A Phase 2 Clinical Trial. JAMA Oncol. 2019, 6, 51-59. [CrossRef]

66. Hong, T.S.; Wo, J.Y.; Yeap, B.Y.; Ben-Josef, E.; McDonnell, E.I.; Blaszkowsky, L.S.; Kwak, E.L.; Allen, J.N.; Clark, J.W.; Goyal, L.; et al. Multi-Institutional Phase II Study of High-Dose Hypofractionated Proton Beam Therapy in Patients With Localized, Unresectable Hepatocellular Carcinoma and Intrahepatic Cholangiocarcinoma. J. Clin. Oncol. 2016, 34, 460-468. [CrossRef]

(C) 2020 by the authors. Licensee MDPI, Basel, Switzerland. This article is an open access article distributed under the terms and conditions of the Creative Commons Attribution (CC BY) license (http://creativecommons.org/licenses/by/4.0/). 